\title{
Histomorphological Spectrum of Ovarian Tumors in A Tertiary Care Hospital
}

\author{
Ashmeet Kaur*, Mansi Faujdar, Tushar Kariya and Shubha Gupta \\ Dept. of Pathology, Santokba Durlabhji Memorial Hospital, Jaipur, India
}

\section{ABSTRACT}

Background: To study or analyse the histomorphological spectrum and distribution of benign and malignant ovarian neoplasms in women of different age groups

Methods: 633 cases of ovarian tumors were studied over a period of 6 years(from July 2011 to July 2017) at the Department of Pathology, SDMH. All the cases were subjected to histopathological examination and IHC as \& when required.

Results: In total,633 ovarian tumor specimens were examined. Out of which ,468 cases (73.9\%)were benign, 23 (3.6\%)were boderline and $142(22.4 \%)$ were malignant. Most of the benign tumors occurred between 31 \& 40 years of age while malignant lesions presented commonly between $41 \& 50$ years of age. Most common histological types were serous cystadenoma (24.18\%) followed by mature cystic teratoma $(22.90 \%)$. The commonest benign tumor was serous cystadenoma \& the commonest malignant tumor was serous cystadenocarcinoma. Serous tumors showed bilateral involvement more commonly than bilateral mucinous tumors.

Conclusion: We noted that serous cystadenoma tumors are the commonest variety of ovarian tumors. Also the age of presentation of these malignant tumors was an earlier age as compared to others.

Keywords: Ovarian Tumors, Histology, Surface Epithelial Tumors, Benign, Borderline, Malignant

\section{Introduction}

Ovarian cancer accounts for about $3 \%$ of all cancers in women. ${ }^{1}$ Ovarian malignancy is the second most common cancer of the female reproductive system and the leading cause of death from gynecologic malignancy. ${ }^{2,3}$ The age adjusted incidence rates of ovarian cancer vary between 5.4 and 8 per 100,000 populations in different parts of the country. ${ }^{4,5}$ Diversity in histological patterns of ovarian tumours is important in diagnosis, treatment as well as prognosis. ${ }^{5}$ Indian Cancer Registry data project ovary as an important site of cancer in women, comprising up to $8.7 \%$ of cancers in different parts of the country. ${ }^{3,6}$ Thus, in this study we highlight the histomorphological spectrum and clinical presentation of patients with ovarian tumors in a tertiary care hospital.

\section{Materials and methods}

This retrospective study included 633 cases of ovarian tumors studied over a period of 6 years. Detailed clinical information were recorded which included age and sex of the patients, signs \& symptoms, FNAC finding of available cases, CBC, USG/CT findings and biochemical investigations like tumor markers CA125, AFP and Beta hCG.

Oophorectomy specimen, ovarian cystectomies, wedge sections as well as hysterectomy with unilateral or bilateral salphing oophorectomy specimens were included in this study. Formalin-fixed, paraffin-embedded tissue sections were stained with Hematoxylin and Eosin and other special stains as and when required. A protocol for SEE-FIM (Sectioning and Extensively examining the Fimbriated end of fallopian tube was followed to detect "early carcinoma". It entails amputation and longitudinal sectioning of the infundibulum and fimbrial segment (distal $2 \mathrm{cms}$ ). The isthmus and ampulla are cut transversely at 2and $3 \mathrm{~mm}$ intervals. IHC stains were performed for further sub-typing whenever required (p53, AFP, PLAP, CK7, CK 20, Inhibin, EMA)

The patients were divided into groups based on WHO classification of ovarian tumors and we studied correlation of histopathological patterns with age, bilaterality, morphology and grading of the tumour

\section{Results}

Total 633 cases of ovarian tumours were studied during a 6-year period of 2011 to 2017.Out of which,468 cases (73.9\%)were benign, $23(3.6 \%)$ were borderline and 142(22.4\%) were malignant as in Table1. The mean age was 32 years with the youngest patient as a case of mature cystic teratoma and oldest as a case of Mucinous cystadenoma. 
Maximum number of cases were seen in the age group of $31-40$ years, 185 cases $(29.2 \%)$. The malignant neoplasms were seen more commonly in the age group of 41-60 years, 33 cases (23.2\% of malignant neoplasms) (Table 3 ). The youngest patient was a 9 month year old girl and the oldest was 72 years old. In the present study, the tumours had an average size of $12.15 \mathrm{~cm}$.(table 2) The largest tumor encountered in the study was mucinous cystadenoma measuring $29 \times 22 \times 14 \mathrm{~cm}$

Of 633 tumours, 338 (53.3\%) were cystic, 255 (40.2\%) were mixed and $40(6.3 \%)$ were solid. 312 Cystic tumours
(49.2\%) were benign. 144 of the 255 cases with mixed consistency were benign and 106 were malignant, whereas out of 40 solid tumours, 12 were benign and 26 malignant as in Table4. Unilateral occurrence was more common than bilateral.Most of the unilateral cases were of mature cystic teratoma. Among the bilateral tumors, serous tumors were the most common tumors.(Table2)

Histologically serous cystadenoma was the most common tumor accounting for $24.18 \%$ followed by mature cystic teratoma $(22.9 \%)$, serous cystadenofibroma (17.71\%) and mucinous cystadenoma(7.59\%)

Table1: Frequency of different classes of ovarian tumors.

\begin{tabular}{|c|c|c|c|c|}
\hline Histological type & Number & Percentage of total tumor & $\mathbf{U} / \mathbf{L}$ & $B / L$ \\
\hline \multicolumn{5}{|l|}{ Surface epithelial tumours } \\
\hline \multicolumn{5}{|l|}{ Benign } \\
\hline Serous cystadenoma & 153 & $24.18 \%$ & 110 & 43 \\
\hline Serous cystadeno-fibroma & 112 & $17.71 \%$ & 71 & 41 \\
\hline Mucinous cystadenoma & 48 & $7.59 \%$ & 43 & 5 \\
\hline Benign brenner tumour & 5 & $0.78 \%$ & 5 & - \\
\hline \multicolumn{5}{|l|}{ Borderline } \\
\hline Borderline serous cystadenoma & 3 & $0.47 \%$ & 1 & 2 \\
\hline Borderline mucinous cystadenoma & 5 & $0.79 \%$ & 3 & 2 \\
\hline \multicolumn{5}{|l|}{ Malignant } \\
\hline Serous cystadenocarcinoma & 45 & $7.10 \%$ & 10 & 35 \\
\hline Mucinous cystadenocarcinoma & 28 & $4.43 \%$ & 11 & 17 \\
\hline Endometroid cystadenofibroma & 1 & $0.15 \%$ & 1 & - \\
\hline Transitional cell carcinoma & - & - & - & - \\
\hline Clear cell adenocarcinoma & 1 & $0.15 \%$ & 1 & - \\
\hline \multicolumn{5}{|l|}{ Germ cell tumours } \\
\hline \multicolumn{5}{|l|}{ Benign } \\
\hline Mature cystic teratoma & 145 & $22.90 \%$ & 128 & 17 \\
\hline Monodermal teratoma & 2 & $0.32 \%$ & 2 & - \\
\hline \multicolumn{5}{|l|}{ Malignant } \\
\hline Immature teratoma & 20 & $3.15 \%$ & 19 & 1 \\
\hline Yolk sac tumor & 8 & $1.26 \%$ & 8 & - \\
\hline Mixed germ cell tumor & 25 & $3.96 \%$ & 15 & - \\
\hline Dysgerminoma & 6 & $0.95 \%$ & 5 & 1 \\
\hline \multicolumn{5}{|l|}{ Sex cord stromal tumour } \\
\hline \multicolumn{5}{|l|}{ Benign } \\
\hline Fibroma & 1 & $0.15 \%$ & 1 & - \\
\hline fibrothecoma & 2 & $0.32 \%$ & 2 & - \\
\hline \multicolumn{5}{|l|}{ Borderline } \\
\hline Granulosa cell tumour & 15 & $2.37 \%$ & 16 & 9 \\
\hline Sertoli cell tumour & - & - & - & - \\
\hline \multicolumn{5}{|l|}{ Malignant } \\
\hline Steroid cell tumors & - & - & - & - \\
\hline $\begin{array}{l}\text { Metastatic tumours (Adenocarcinoma and signet ring } \\
\text { cell carcinoma) }\end{array}$ & 3 & $0.47 \%$ & 3 & - \\
\hline Undifferentiated or poorly differentiated tumors & 5 & $0.80 \%$ & 4 & 1 \\
\hline Total & 633 & $100 \%$ & 429 & 204 \\
\hline
\end{tabular}


Table2. Distribution of ovarian tumors as per WHO Classification and laterality

\begin{tabular}{|c|c|c|c|c|c|}
\hline Class of tumor & No. & $\%$ of all tumors & Benign & Borderline & Malignant \\
\hline Germ cell tumor & 196 & 30.96 & 147 & - & 59 \\
\hline Surface epithelial tumor & 401 & 63.34 & 318 & 8 & 75 \\
\hline Sex cord-stromal tumor & 28 & 4.43 & 3 & 15 & - \\
\hline Secondary (metastatic) tumor & 3 & 0.47 & - & - & 3 \\
\hline Undifferentiated/Poorly differentiated tumors & 5 & 0.78 & - & - & 5 \\
\hline Total & 633 & $100 \%$ & 468 & 23 & 142 \\
\hline
\end{tabular}

Table 3.Distribution of ovarian neoplasms by age and type

\begin{tabular}{|c|c|c|c|c|c|c|c|c|c|c|}
\hline \multirow{2}{*}{\multicolumn{2}{|c|}{$\begin{array}{l}\text { Histopathological types } \\
1 \text { to } 10\end{array}$}} & \multicolumn{8}{|c|}{ Age in years } & \multirow{2}{*}{ Total } \\
\hline & & 11 to 20 & 21 to 30 & 31 to 40 & 41 to 50 & 51 to 60 & 61 to 70 & 71 to 80 & & \\
\hline \multirow{8}{*}{$\begin{array}{l}\text { Benign } \\
\text { Tumors }\end{array}$} & Serous cystadenoma & 10 & 13 & 42 & 38 & 22 & 25 & 3 & - & 153 \\
\hline & $\begin{array}{l}\text { Mucinous } \\
\text { Cystadenoma }\end{array}$ & 3 & 3 & 10 & 20 & 10 & - & 2 & - & 48 \\
\hline & $\begin{array}{l}\text { Serous } \\
\text { Cystadenofibroma }\end{array}$ & 3 & 11 & 29 & 32 & 24 & 8 & 3 & 2 & 112 \\
\hline & Benign Brenner tumor & - & - & - & 1 & 2 & 2 & - & - & 5 \\
\hline & Mature cystic teratoma & 4 & 12 & 48 & 56 & 22 & 3 & - & - & 145 \\
\hline & Monodermal teratoma & - & - & 1 & 1 & - & - & - & - & 2 \\
\hline & Fibroma & - & - & - & 1 & - & - & - & - & 1 \\
\hline & Fibrothecoma & - & - & - & 2 & - & - & - & - & 2 \\
\hline \multirow{4}{*}{$\begin{array}{l}\text { Broderline } \\
\text { malignant }\end{array}$} & Mucinous cystadenoma & - & - & 1 & 3 & 1 & - & - & - & 5 \\
\hline & Serous cystadenoma & - & - & 1 & 2 & - & - & - & - & 3 \\
\hline & Granulosa cell tumor & 1 & 2 & 1 & 3 & 4 & 2 & 1 & 1 & 15 \\
\hline & Sertoli cell tumor & - & - & - & - & - & - & - & - & - \\
\hline \multirow{11}{*}{$\begin{array}{l}\text { Malignant } \\
\text { Tumor }\end{array}$} & $\begin{array}{l}\text { Serous } \\
\text { cystadenocarcinoma }\end{array}$ & - & - & 3 & 7 & 20 & 3 & 12 & - & 45 \\
\hline & $\begin{array}{l}\text { Mucinous } \\
\text { cystadenocarcinoma }\end{array}$ & - & 3 & 2 & 9 & 6 & 5 & 3 & - & 28 \\
\hline & $\begin{array}{l}\text { Endometrioid } \\
\text { cystadenofibroma }\end{array}$ & - & - & - & 1 & - & - & - & - & 1 \\
\hline & $\begin{array}{l}\text { Clear cell } \\
\text { adenocarcinoma }\end{array}$ & - & - & - & - & 1 & - & - & - & 1 \\
\hline & $\begin{array}{l}\text { Transitional cell } \\
\text { carcinoma }\end{array}$ & - & - & - & - & - & - & - & - & - \\
\hline & Immature teratoma & 1 & 2 & 12 & 4 & 1 & - & - & - & 20 \\
\hline & Dysgerminoma & - & 2 & 4 & - & - & - & - & - & 6 \\
\hline & Yolk sac tumor & 3 & 4 & 1 & - & - & - & - & - & 8 \\
\hline & Mixed germ cell tumor & 3 & 7 & 10 & 3 & 2 & - & - & - & 25 \\
\hline & Metastasis (Secondary) & - & - & - & 2 & 1 & - & - & - & 3 \\
\hline & $\begin{array}{l}\text { Undifferentiated or } \\
\text { poorly differentiatied } \\
\text { tumors }\end{array}$ & - & - & - & - & 3 & 2 & - & - & 5 \\
\hline Total & & 28 & 59 & 165 & 185 & 119 & 50 & 24 & 3 & 633 \\
\hline
\end{tabular}


Table 4: Consistency of ovarian tumors.

\begin{tabular}{|l|c|c|c|c|}
\hline Leison & Solid + Cystic & Cystic & Solid & 12 \\
\hline Benign & 144 & 312 & 2 & 468 \\
\hline Borderline & 5 & 16 & 26 & 23 \\
\hline Malignant & 116 & - & $\mathbf{4 0}$ & $\mathbf{6 3 3}$ \\
\hline Total & $\mathbf{2 6 5}$ & $\mathbf{3 2 8}$ & & \\
\hline
\end{tabular}

Table 5: Relationship between size of tumor and histological type.

\begin{tabular}{|c|c|c|c|c|c|c|c|}
\hline \multirow{2}{*}{\multicolumn{2}{|c|}{ Histopathological types }} & \multirow{3}{*}{$\begin{array}{c}\begin{array}{c}\text { Mean Size } \\
(\mathrm{cm}) \pm \text { SD }<4\end{array} \\
12.5 \pm 3.9\end{array}$} & \multicolumn{4}{|c|}{ Size of tumor (cms) } & \multirow{3}{*}{$\begin{array}{r}\text { Total } \\
153\end{array}$} \\
\hline & & & $5-9$ & $10-19$ & $>20$ & & \\
\hline \multirow{8}{*}{$\begin{array}{l}\text { Benign } \\
\text { Tumors } \\
(8.93 \pm 3.92 \mathrm{~cm})\end{array}$} & Serous cystadenoma & & 12 & 84 & 46 & 11 & \\
\hline & Mucinous Cystadenoma & $15.9 \pm 7.0$ & 3 & 15 & 25 & 5 & 48 \\
\hline & Serous Cystadenofibroma & $10.5 \pm 4.2$ & 9 & 43 & 59 & 1 & 112 \\
\hline & Benign Brenner tumor & $3.5 \pm 1.1$ & 4 & 1 & - & - & 5 \\
\hline & Mature cystic teratoma & $10.8 \pm 3.8$ & 19 & 103 & 22 & 1 & 145 \\
\hline & Monodermal teratoma & $5.2 \pm 1.4$ & - & 2 & - & - & 2 \\
\hline & Fibroma & 7.5 & - & 1 & - & - & 1 \\
\hline & Fibrothecoma & $5.5 \pm 1.2$ & - & 2 & - & - & 2 \\
\hline \multirow{4}{*}{$\begin{array}{l}\text { Borderline } \\
\text { Malignant } \\
(16.13 \pm 5.53 \mathrm{~cm})\end{array}$} & Mucinous cystadenoma & $18.2 \pm 4.8$ & - & 1 & 2 & 2 & 5 \\
\hline & Serous cystadenoma & $14.0 \pm 6.2$ & - & - & 2 & 1 & 3 \\
\hline & Granulosa cell tumor & $16.2 \pm 5.6$ & 1 & 5 & 9 & - & 15 \\
\hline & Sertoli cell tumor & - & - & - & - & - & - \\
\hline \multirow{11}{*}{$\begin{array}{l}\text { Malignant } \\
\text { Tumor } \\
(11.41 \pm 4 \mathrm{~cm})\end{array}$} & Serous cystadenocarcinoma & $16.0 \pm 5.2$ & 1 & 19 & 23 & 2 & 45 \\
\hline & Mucinous cystadenocarcinoma & $19.5 \pm 4.6$ & - & 5 & 19 & 4 & 28 \\
\hline & Endometrioid Cystadenofibroma & 9.5 & - & 1 & - & - & 1 \\
\hline & Clear cell adenocarcinoma & 8.5 & - & 1 & - & - & 1 \\
\hline & Transitional cell carcinoma & - & - & - & - & - & - \\
\hline & Immature teratoma & $14.8 \pm 3.2$ & 1 & 4 & 13 & 2 & 20 \\
\hline & Dysgerminoma & $13.0 \pm 5.0$ & 1 & 3 & 2 & - & 6 \\
\hline & Yolk sac tumor & $13.4 \pm 5.2$ & - & 3 & 5 & - & 8 \\
\hline & Mixed germ cell tumor & $10.2 \pm 4.8$ & 1 & 14 & 10 & - & 25 \\
\hline & Metastasis (Secondary) & $5.5 \pm 1.2$ & - & 3 & - & - & 3 \\
\hline & $\begin{array}{l}\text { Undifferentiated or poorly differentiated } \\
\text { tumors }\end{array}$ & $15.2 \pm 2.8$ & 1 & 1 & 3 & - & 5 \\
\hline Total & & $12.15 \pm 4.48$ & 53 & 311 & 240 & 29 & 633 \\
\hline
\end{tabular}




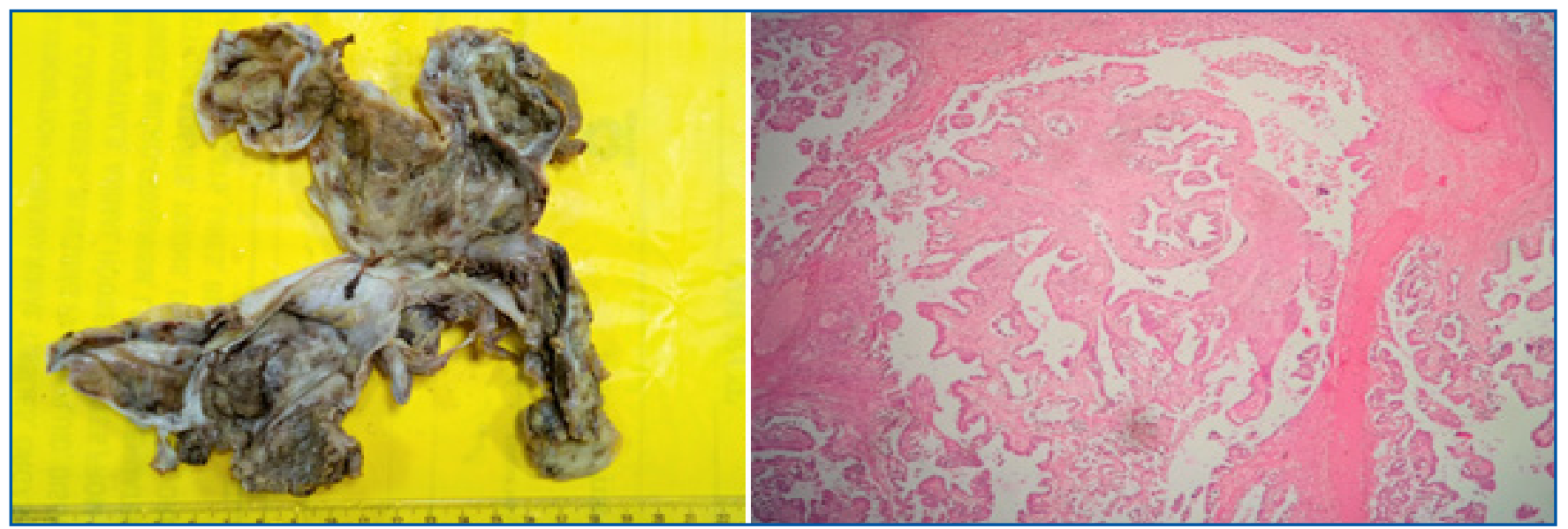

Fig. 1: Serous papillary cystadenocarcinoma-a) Grossly, cut surface shows a cystic tumor with few solid areas. Papillary excrescenses also seen. b) On histology, moderately differentiated tumor composed of crowed papillae lined by pleomorphic cells.

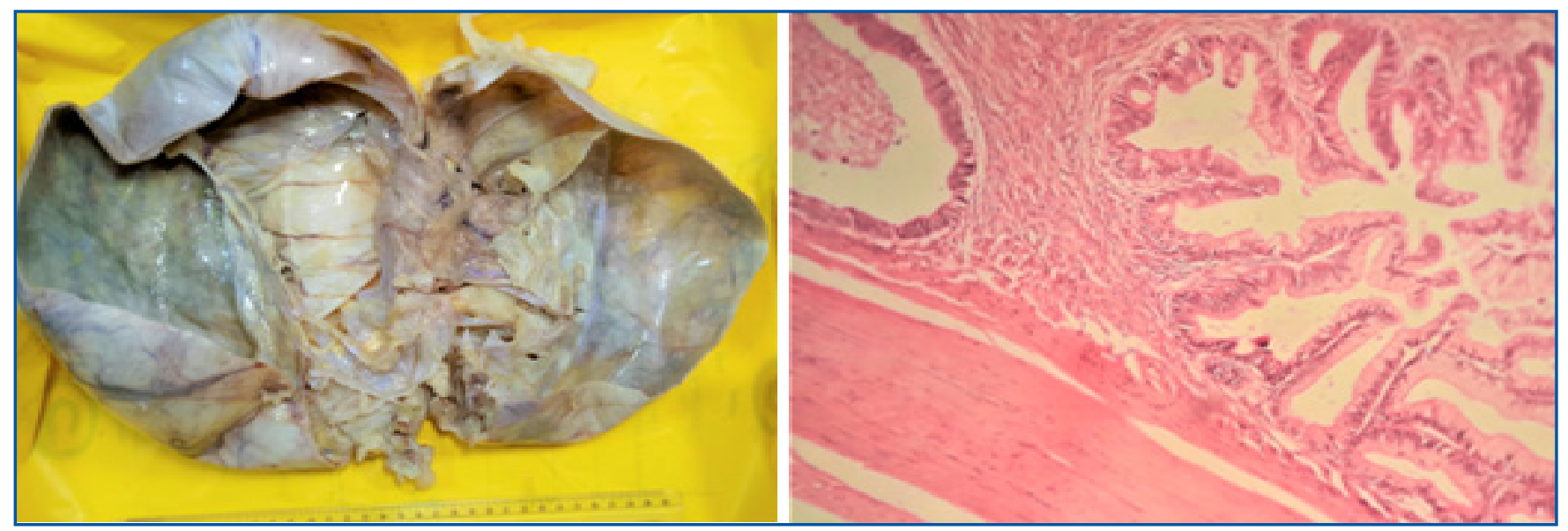

Fig. 2: Borderline mucinous tumor-a)Grossly, cut surface shows a multiloculated tumor with focal solid areas. b) Histologically, the photomicrograph shows a well encapsulated ovarian tumor. Stratified mucinous epithelium with nuclear enlargement and hyperchromasia is seen.

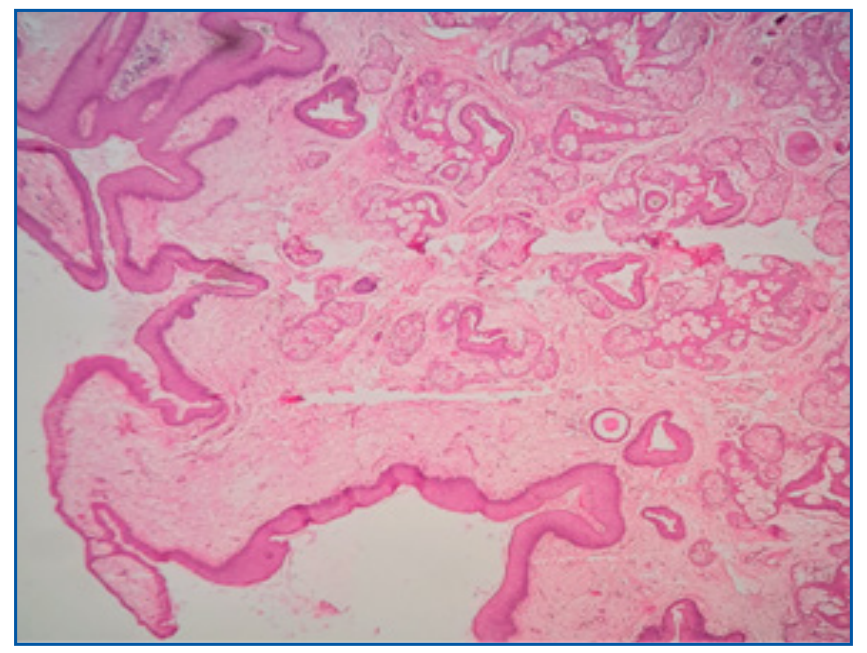

Fig. 3: Mature cystic teratoma-Histologically, a cyst lined by keratinized squamous epithelium with underlying cutaneous structures. 


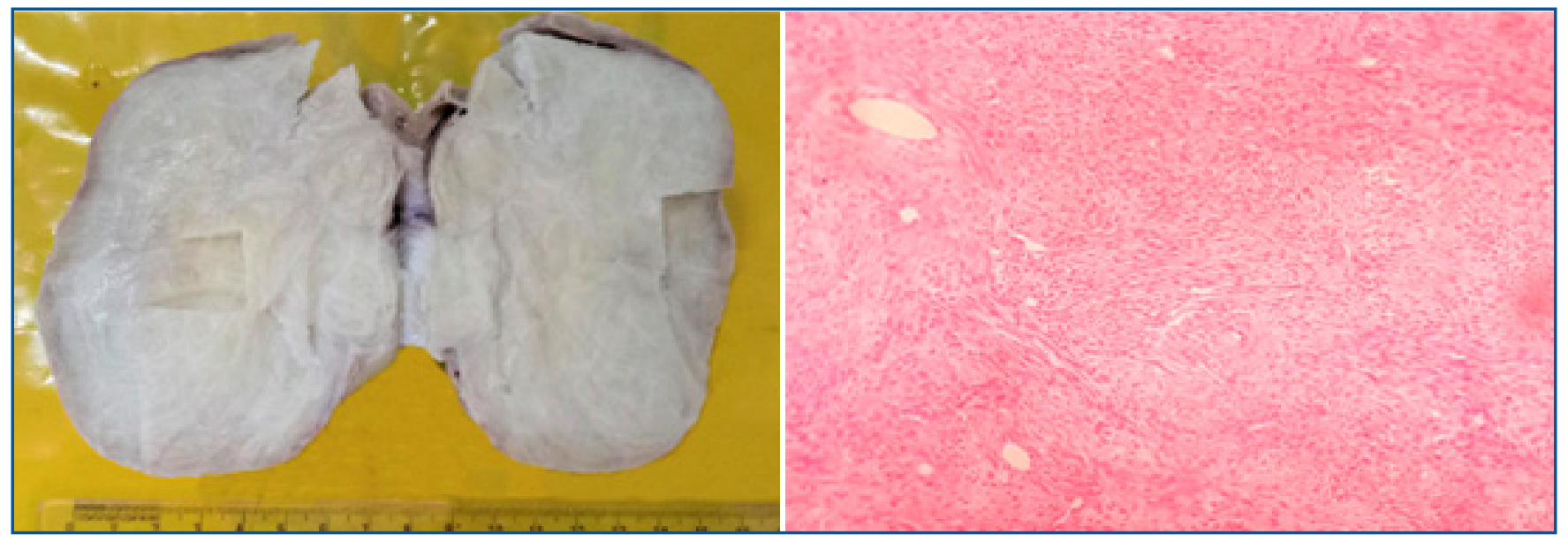

Fig. 4: Thecoma-a)Cut surface shows a well circumscribed tan yellow solid tumor mass replacing the ovary. b)Microscopically, the tumor is composed predominantly of plump spindle cells with pale cytoplasm.

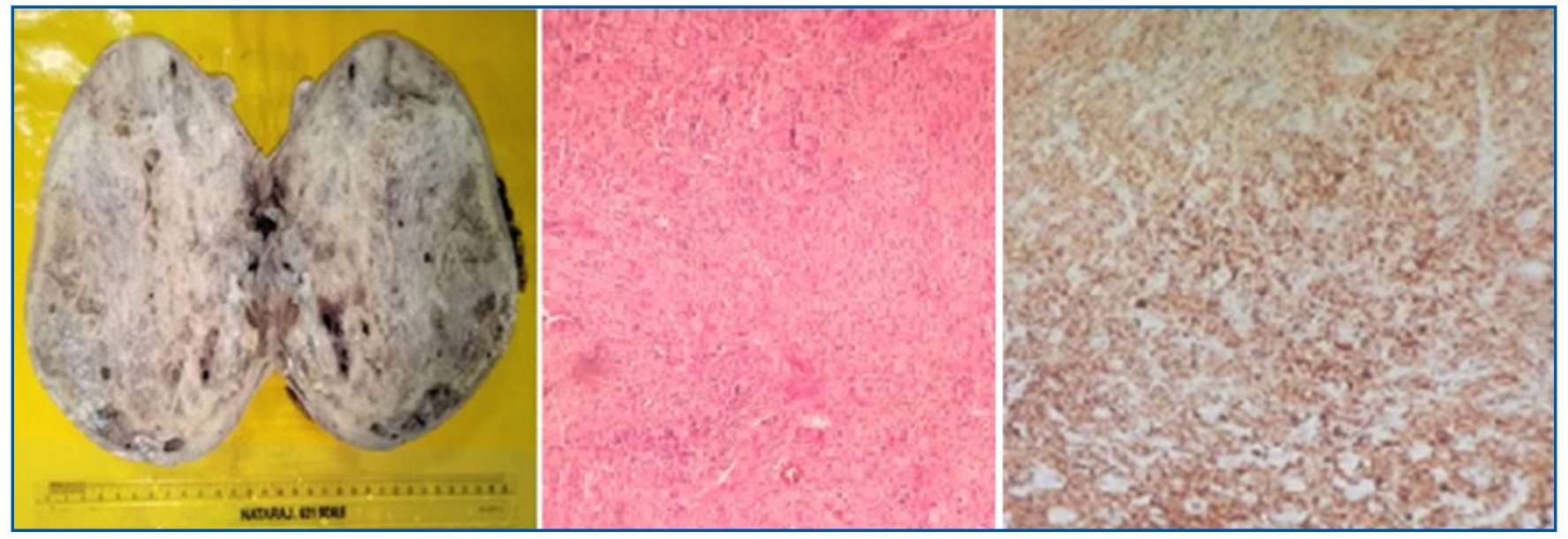

Fig. 5: Granulosa cell tumor- a) Grossly, cut surface shows variegated tan appearance. b) Microscopically, the tumor is composed of diffuse sheets of tumor cells with round to oval nuclei, nuclear grooves and inconspicuous nuclei. c) Tumor cells are positive for inhibin.

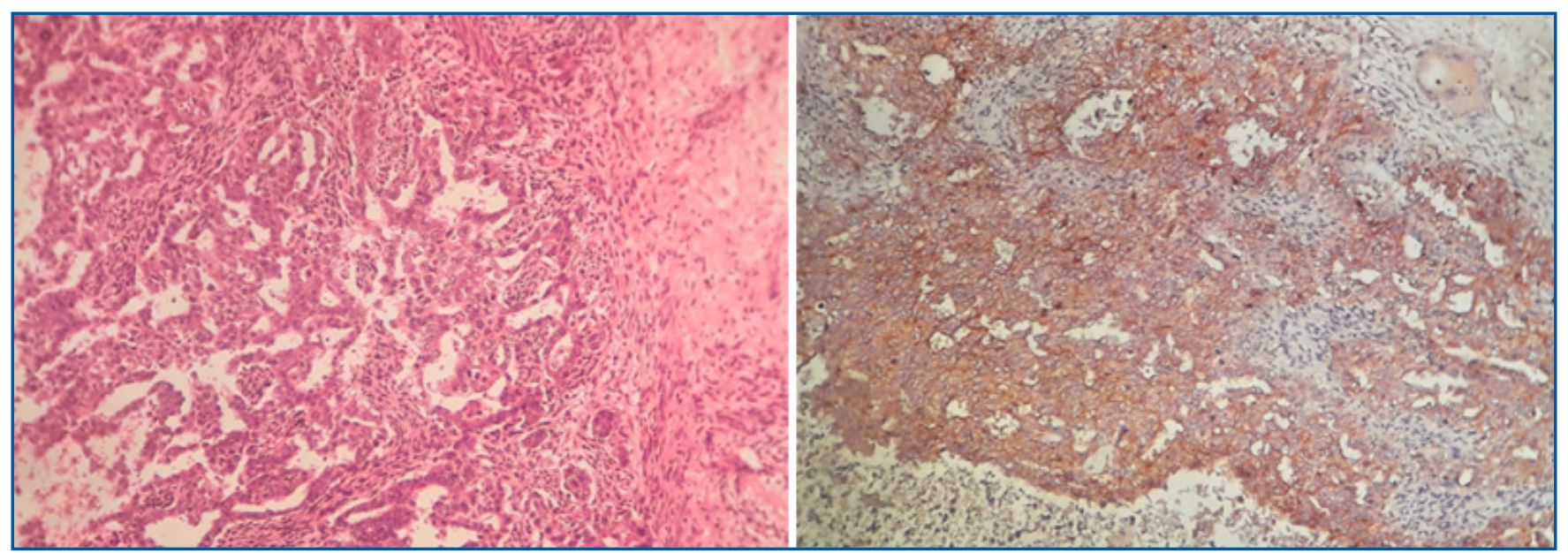

Fig. 6: Embryonal cell carcinoma. a) Histologically sheet like growth pattern of anaplastic malignant germ cells is seen. b) tumor cells are immunopositive for CD30. 


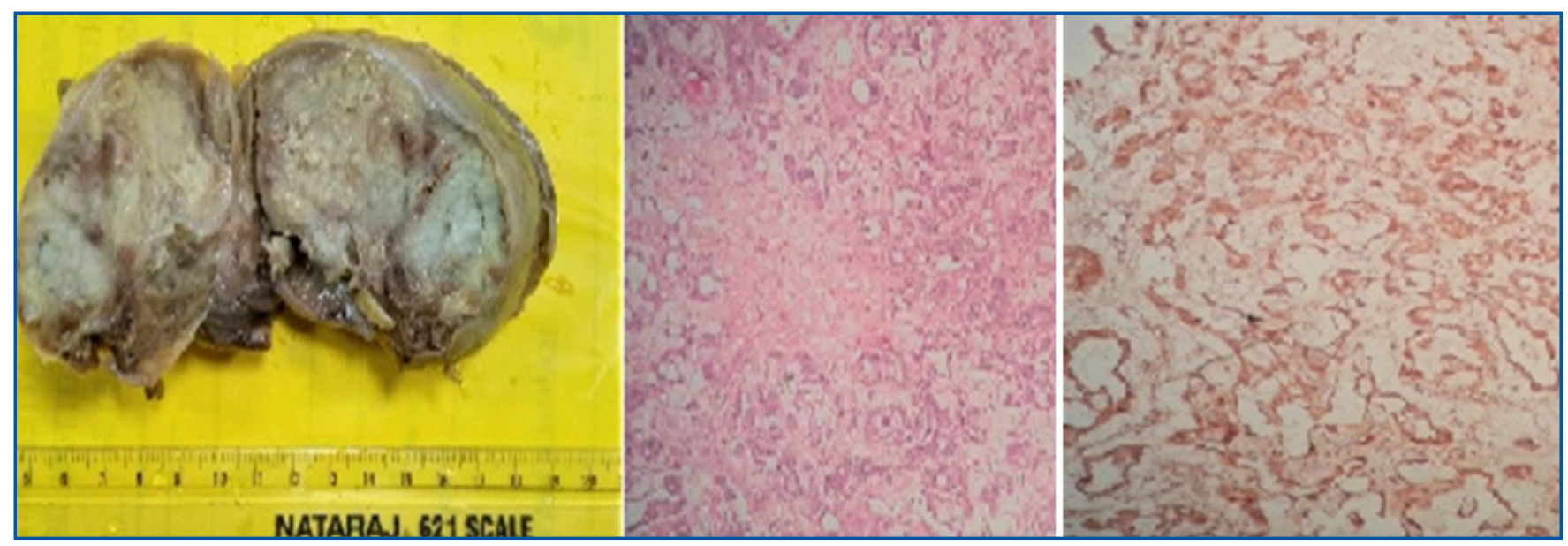

Fig. 6: Embryonal cell carcinoma. a) Histologically sheet like growth pattern of anaplastic malignant germ cells is seen. b) tumor cells are immunopositive for CD30.

\section{Discussion}

Ovarian tumors are regarded as one of the most complex tumour of women in terms of histiogenesis, clinical behaviour and malignant potentiality. It represents the sixth most common female cancer and the fourth leading cause of death due to cancers in women. ${ }^{7,8}$ Histomorphological classification of ovarian tumours forms an integral part of the evaluation of the neoplasms. ${ }^{8,9}$

In the present study, a total 633 ovarian tumor specimens were examined. Out of which ,468 cases (73.9\%)were benign, $23(3.6 \%)$ were boderline and 142(22.4\%)were malignant. Similar results were observed by Gupta $\mathrm{N}$ et al and Maheshwari $\mathrm{V}$ et al where benign tumours constituted $71.9 \%$ in each study, borderline tumours constituted $4.4 \%$ and $4.1 \%$, and malignant tumours constituted $23.7 \%$ and $22.9 \%$ of tumors respectively. $8,10,11,12$

WHO classification of ovarian tumours is based on the tissue of origin of the tumours which have been found to arise from one of three ovarian components: (1) surface epithelium (2) the germ cells and (3) the stroma of the ovary. ${ }^{8}$ Among histopathological patterns the commonest category of the ovarian tumours encountered in our series as surface epithelial tumours followed by germ cell tumours. This observation is consistent with other studies conducted by Ahmad $\mathrm{Z}$ et al , Pilli et al and Malik et al ${ }^{5,13,14,15}$

The most common benign tumour were serous cystadenoma (24.18\%) followed by mature cystic teratoma $(22.90 \%)$ , similar results reported by Yasmin et $\mathrm{al}^{16}$ and Pachori et al.${ }^{17}$ Mucinous tumors were seen in $12 \%$ cases of all ovarian tumors, which is similar to the studies conducted by Pachori et al where mucinous tumors constituted $14.87 \% .{ }^{17}$ The commonest malignant tumor was serous cystadenocarcinoma. Similiarly, Sheikh S also observed that most of the malignant tumours, about $90 \%$ were also of the epithelial origin. ${ }^{8}$

When the tumor is confined to the ovaries, such as in borderline tumor, intraepithelial carcinoma and microinvasive carcinoma (with stromal invasive foci $<10 \mathrm{~mm}^{2}$ ), the prognosis is good as compared to carcinoma with invasive implant or carcinoma with peritoneal lesions like pseudomyxoma peritonei. ${ }^{18}$

Common problems encountered while diagnosing tumors of Epithelial origin especially serous and mucinous ovarian tumors is that tumor may include benign and borderline components in one area and malignant counterpart in other area. Therefore, extensive sampling including including upto 1 histological section per $1-2 \mathrm{cms}$ of tumor diameter as well as sampling of suspicious lesions (solid area or mural nodule) is essential. Also, at times, it is difficult to differentiate primary tumor from metastatic carcinoma from appendix, large intestine, stomach, pancreas or cervix. The tumor morphology of these tumors resemble primary mucinous ovarian carcinoma.IHC staining such as CK7 and CK20 ,along with clinical information evaluation , is necessary to determine the origin of the cancer. ${ }^{18,19}$

One case $(0.15 \%)$ of endometrioid carcinoma in this study, which was lower than the percentage of Ahmad Z et al ${ }^{13}$, Zaman et al ${ }^{20}$ and pachori et $\mathrm{al}^{17}$ studies $12.03 \%$ , $3.87 \%$ and $0.41 \%$ respectively. In this study, $2.37 \%$ of granulosa cell tumors were seen, which was comparable to the study conducted by Zaman et al ${ }^{20}$ and pachori et al.$^{17}$ Fibroma were encountered in $0.15 \%$ of cases in this study as observed in the study which were similar to the results found by pachori et al. ${ }^{1}$ 
Most of the benign tumors occurred between $31 \& 40$ years of age while malignant lesions presented commonly between $41 \& 50$ years of age. Similiarly sheikh $\mathrm{S}^{8}$ observed that with maximum number of cases in 21-30 years, $43.5 \%$. However, a study by Murthy $\mathrm{NS}^{21}$ et al, involving data across various cities in India, revealed that the incidence of ovarian cancer increases from 35 years of age reaching its peak between 55-64 years. Though similar age related trends were followed by malignant tumours in our study but a fair percentage $(21.9 \%)$ of malignant neoplasms especially surface epithelial adenocarcinomas was also seen in younger age groups ( $<30$ years). This can be attributed to the possible effects of environmental and life style changes adopted by younger population. ${ }^{21}$

The mean size of ovarian tumors were $12.15 \mathrm{~cm}$. The largest tumor encountered in the present study was a mucinous cystadenoma measuring $29 \times 22 \times 14 \mathrm{~cm}$ in size. Similar observation was made by Pachori et al ${ }^{17}$ who reported a mucinous cystadenoma with a maximum diameter of 35 $\mathrm{cm}$. Serous tumors showed bilateral involvement more commonly than bilateral mucinous tumors. Benign tumors (49.2\%) were more often cystic in consistency in this study, which was comparable to the results of Kanthikar et al and Pachori et al. ${ }^{17,22}$ All the malignant tumors had solid consistency which was also comparable to the study of Kanthikar et al and pachori et al. ${ }^{17,22}$ Thus, the present study gives the most comprehensive picture of the current state of ovarian tumor incidence and histopathological pattern.

\section{Conclusion}

To conclude, histomorphologically, majority of the ovarian tumors are benign. Among the malignant tumors, tumors originating from surface epithelium are the commonest. Awareness among public and doctors is essential for early detection and treatment of ovarian lesions.

\section{References}

1. Agrawal P, Kulkarni DG, Chakrabarti PR, Chourasia Sapna, Dixit Monal,et al. Clinicopathological Spectrum of Ovarian Tumors: A 5-Year Experience in a Tertiary Health Care Center. Journal of Basic and Clinical Reproductive Sciences 2015 . July 4 (2) :90-6

2. Tortolero-Luna G, Mitchell MF. The epidemiology of ovarian cancer. J Cell Biochem Suppl 1995;23:200-7

3. Mondal SK, Banyopadhyay R, Nag DR, Roychowdhury S, Mondal PK, Sinha SK. Histologic pattern, bilaterality and clinical evaluation of 957 ovarian neoplasms: A 10-year study in a tertiary hospital of eastern India. J Can Res Ther 2011;7:433-7.
4. Consolidated Report of Population Based Cancer Registries 2001-2004. National Cancer Registry Program Indian Council of Medical Research. Bangalore, 2006.

5. Nishal AJ ,Naik KS, Modi Jigna. Int J Res Med Sci. 2015 Oct;3(10):2714-2717

6. Murthy NS, Shalini S, Suman G, Pruthvish S, Mathew A. Changing trends in incidence of ovarian cancer - the Indian scenario. Asian Pac J Cancer Prev 2009;10:1025-30

7. Tortolero L, Mictchell FM, Rhodes HE. Epidemiology and screening of ovarian cancer. Obstet Gynecol Clin North Am. 1994;21:63-75.

8. Sheikh S , Humaira Bashir, Summyia Farooq,Arshi Beigh, Farzana Manzoor, et al. Int J Res Med Sci. 2017 May;5(5):2110-2114

9. Saxena MHK, Devi G, Prakash P, Pantrajan P. Ovarian neoplasms-A retrospective study of 356 cases. J Obstret Fynec India. 1980;30:522-7

10. Gupta N, Bisht D, Agarwal AK, Sharma VK. Retrospective and prospective study of ovarian tumours and tumour like lesions. Indian J Pathol Microbiol. 2007;50:525-7.

11. Gupta GC, Singh PA, Mehrotra TN, Agarwal R: A clinicopathological study of ovarian tumours. Indian $\mathrm{J}$ Pathol Microbiol. 1986;29:354-62

12. Maheshwari V, Tyagi SP, Saxena K, Tyagi N, Sharma R, Aziz M, Hameed F. Surface epithelial tumours of the ovary. Indian J Pathol Microbiol. 1994;37:75-85.

13. Ahmad Z, Kayani N, Hasan S, Muzaffar S, Gill M. Histopathological pattern of ovarian neoplasms. J Pak Med Assoc. 2000;50(12):416-9.

14. Pilli G S, Suneeta KP, Dhaded A V, Yenni VV. Ovarian tumours: a study of 282 cases: J Indian Med Assoc. 2002;100:420:423-4.

15. Malik IA. A Prospective Study of Clinicopathological Features of Epitheliall Ovarian Cancer in Pakistan. J Pak Med Assoc. 2002;52(4):155-8.

16. Yasmin S, Yasmin A, Asif M. Clinicohistological pattern of ovarian tumors in Peshawar region. J Ayub Med Coll Abbottabad 2008; 20(4):11-3.

17. Pachori G, Meena US, Sunaria RK, Pachori P, Jethani N, Bayla $\mathrm{T}$ et al. Histopathological study of ovarian tumors in Ajmer region. Int J Med Sci Public Health 2016;5: 1400-03

18. Kushima Miki.Problems in the pathological diagnosis and Intraoperative rapid diagnosis of mucinous tumor of the ovary.Showa Uni Med Sci $2013 ; 25(1): 1-7$

19. Lee KR, Tavassoli FA, Prat J, et al. Surface epitheliastromal tumors. In Tavassolt FA, Devtlee P, eds. Pathology and genetics of tumors of the breast and female genital organs. Lyon: IARC Press, 2003. Pp117-145. (World health organization classification of tumors; 4) 
20. Zaman S, Majid S, Hussain M, Chughtai O, Mahboob J, Chughtai S. A retrospective study of ovarian tumours and tumour-like lesions. J Ayub Med Coll Abbottabad 2010;22(1):104-8

21. Murthy NS, Shalini S, Suman G, Pruthvish S, Mathew A. Changing trends in incidence of ovarian cancer- the Indian scenario. Asian Pac J cancer prev. 2009;10(6):1025-30

22. Kanthikar SN, Dravid NV, Deore PN, Nikumbh DB, Suryawanshi KH. Clinico-histopathological analysis of neoplastic and non- neoplastic lesions of the ovary: a 3-year prospective study in Dhule, North Maharashtra, India. J Clin Diagn Res 2014;8(8): 4-7.

*Corresponding author:

Dr. Ashmeet Kaur, Senior Resident, Dept. of Pathology, Santokba Durlabhji Memorial Hospital, Jaipur, India

Email: ashmeetkochar@gmail.com 